\title{
Frost-Susceptibility Testing
}

and Predictions for the Raymark Superfund Site

Vincent C. Janoo, Lynette A. Bama, and Shem A. Orchino 
Abstract: This project was conducted to assist in predicting the effects of freeze-thaw cycling on Tilcon common granular fill during the freezing season. This material is being used as the subbase material in the proposed pavement structure at the Raymark Superfund site in Stratford, Connecticut. Based on the initial laboratory results of the Tilcon material performed at CRREL, the amount of fines passing the no. 200 sieve was found to be in the vicinity of $20 \%$, of which approximately $14 \%$ was finer than $0.02 \mathrm{~mm}$. Results from the frost heave tests indicate that when the Tilcon material is saturated, based on the rate of heave, the material is classified a high to very high frost-susceptible material. In the unsaturated condition, the material is classified as a low to medium frost-susceptible material. Computer simulations were run to predict the amount of frostheave and frost penetration that may be expected on this site during the freezing season. Results from the laboratory frost-susceptibility tests and computer simulations were then used to estimate the amount of cumulative damage to the pavement structure during its design life.

How to get copies of CRREL technical publications:

Department of Defense personnel and contractors may order reports through the Defense Technical Information Center:

DTIC-BR SUITE 0944

8725 J OHN J KINGMAN RD

FT BELVOIR VA 22060-6218

Telephone 18002253842

E-mail help@dtic.mil

msorders@dtic.mil

WWW http://www.dtic.dla.mil/

All others may order reports through the National Technical Information Service:

NTIS

5285 PORT ROYAL RD

SPRINGFIELD VA 22161

Telephone 17034874650

E-mail $\quad \begin{aligned} & 17034874639 \text { (TDD for } \\ & \text { orders@ntis.fedworld.gov }\end{aligned}$

WWW http://www.fedworld.gov/ntis/ntishome.html

A complete list of all CRREL technical publications is available from

USACRREL (CECRL-LP)

72 LYME RD

HANOVER NH 03755-1290

Telephone 16036464338

E-mail techpubs@crrel.usace.army.mil

For information on all aspects of the Cold Regions Research and Engineering Laboratory, visit our World Wide Web site: http://www.crrel.us ace. army.mil 


\section{Special Report 97-31}

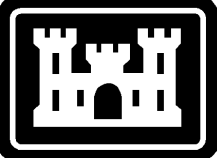

US Army Corps of Engineers

Cold Regions Research \& Engineering Laboratory

\section{Frost-Susceptibility Testing and Predic tions for the Raymark Superfund Site}

Vincent C. J a noo, Lynette A. Bama, and Shemi A. Orchino 


\section{PREFACE}

This report was prepared by Dr. Vincent C. Janoo, Research Civil Engineer, Lynette A. Barna, Civil Engineer, and Sherri A. Orchino, Civil Engineering Technician, Civil Engineering Research Division, Research and Engineering Directorate, U.S. Army Cold Regions Research and Engineering Laboratory, Hanover, New Hampshire. Funding was provided by the U.S. Environmental Protection Agency (EPA) through the U.S. Army Corps of Engineers, New England District (NED).

The authors wish to acknowledge the efforts and assistance of the EPA, NED's Geotechnical Engineering Section, Foster Wheeler Environmental Corporation, and the Stratford Resident Office for making this project possible. The authors thank Anthony Firicano of NED and Jeffrey Stark of CRREL for technically reviewing the manuscript of this report.

The contents of this report are not to be used for advertising or promotional purposes. Citation of brand names does not constitute an official endorsement or approval of the use of such commercial products. 


\section{CONTENTS}

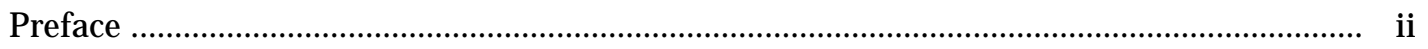

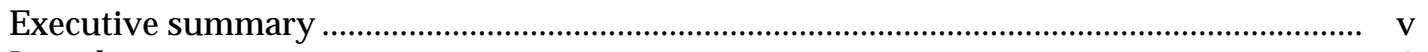

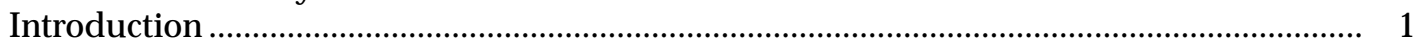

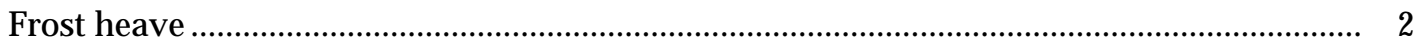

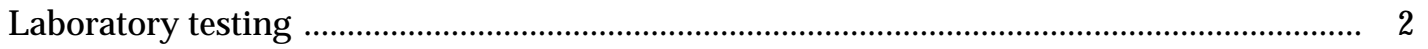

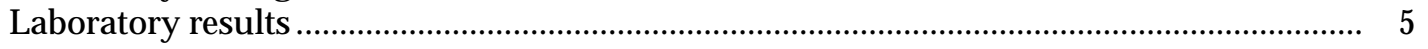

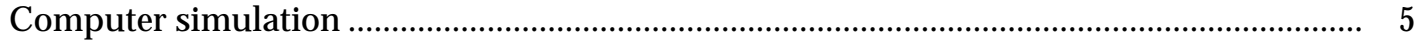

CRREL FROST model ………………................................................................................ 5

Layer thickness ................................................................................................................ 7

Soil type and soil properties ...................................................................................... 8

Water table depth .......................................................................................................... 8

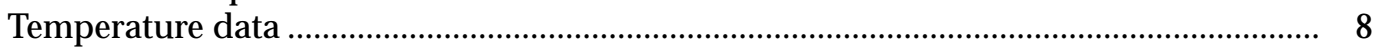

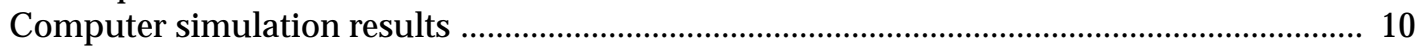

640-mm Tilcon subbase material thickness …………........................................................ 10

460-mm Tilcon material thickness ................................................................................. 11

560-mm graded aggregate base thickness …………..................................................... 12

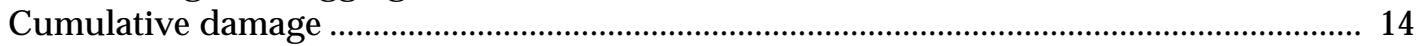

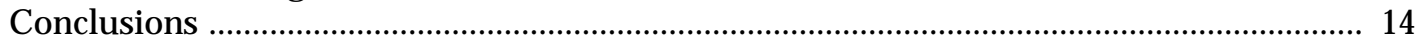

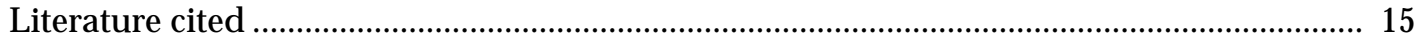

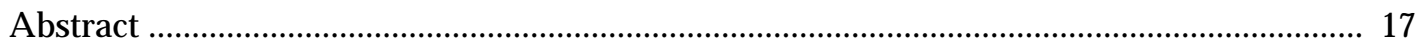

\section{ILLUSTRATIONS}

Figure

1. Grain size distribution for Tilcon common granular fill material .................................. 2

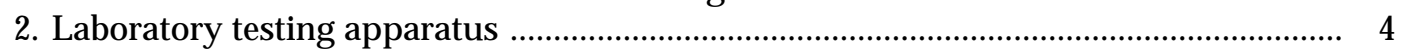

3. Frost-susceptibility testing for saturated soil samples ...................................................... 4

4. Sample moisture profile for saturated samples ................................................................. 4

5. Frost-susceptibility testing for unsaturated soil samples ................................................ 5

6. Sample moisture profile for unsaturated samples ......................................................... 5

7. Pavement structure with 640-mm Tilcon layer modeled in FROST ................................. 6

8. Pavement structure with 460-mm Tilcon layer modeled in FROST ................................ 6

9. Pavement structure with 560-mm graded base modeled in FROST …............................ 7

10. Annual freezing index curve for 1993-94 freezing season ............................................... 9

11. Annual freezing index curve for 1977-78 freezing season ............................................ 9

12. Annual freezing index curve for 1976-77 freezing season ............................................. 10

13. Average daily temperature curve for 1977-78 freezing season ......................................... 10

14. FROST prediction of cumulative mean heave-640-mm subbase layer ........................... 11

15. FROST prediction of frost penetration-640-mm subbase layer .................................... 11

16. FROST prediction of cumulative mean heave-460-mm subbase layer ........................... 12

17. FROST prediction of frost penetration-460-mm subbase layer ...................................... 12

18. FROST prediction of cumulative mean heave-560-mm base layer ................................ 13

19. FROST prediction of frost penetration - 560-mm base layer ............................................. 13 


\section{TABLES}

Table

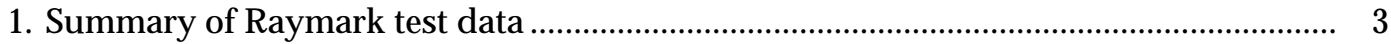

2. Criteria for determining frost-susceptibility test ........................................................ 6

3. Distribution of elements through pavement structure, $640-\mathrm{mm}$ Tilcon subbase layer . 7

4. Distribution of elements through pavement structure, 460-mm Tilcon subbase layer . 7

5. Distribution of elements through pavement structure, $560-\mathrm{mm}$ base course layer ...... 7

6. Summary of soils used in FROST model for simulation …….......................................... 8

7. Example of determining cumulative degree-days ……................................................... 9

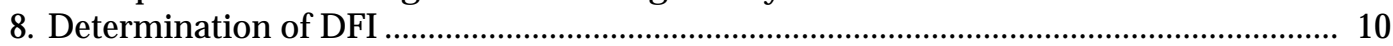

9. Summary of frost heave and frost depth predictions from computer simulation ......... 13 


\section{EXECUTIVE SUMMARY}

CRREL was approached by the Geotechnical Engineering Division of the New England Division (NED), U.S. Army Corps of Engineers, to assist in predicting the effects of freeze-thaw cycling on pavement design during the freezing season on Tilcon common granular fill. This Tilcon common granular fill is being used as the subbase material in the proposed pavement structure at the Raymark Superfund site in Stratford, Connecticut. The Tilcon material is considered to be a clean material that comes from a source in North Branford, Connecticut.

Based on the initial laboratory results of the Tilcon common granular fill material performed at CRREL, the amount of fines passing the no. 200 sieve was found to be in the vicinity of $20 \%$, of which approximately $14 \%$ was finer than $0.02 \mathrm{~mm}$. Results from the frost heave tests indicate that when the Tilcon material is saturated, based on the rate of heave, the material is classified as a high to very high frost-susceptible material. In the unsaturated condition, the material is classified as a low to medium frost-susceptible material.
Four computer simulations were run to predict the amount of frost heave. Two of the simulations used a Tilcon subbase layer of $640 \mathrm{~mm}$ and varied the depth of the water table to $100 \mathrm{~mm}$ below the pavement surface, simulating a saturated soil, and a water table depth of $2740 \mathrm{~mm}$ for a soil containing low moisture. The remaining two simulations used the same water table depths, but decreased the layer of the Tilcon subbase to $460 \mathrm{~mm}$.

Overall, the computer simulations predicted frost heave levels of 45 and $47 \mathrm{~mm}$ with saturated soil for the 640- and 460-mm subbase thicknesses, respectively, and significantly lower levels of frost heave with moist soil $(5.3$ and $6.7 \mathrm{~mm})$. The amount of frost penetration for saturated soils was 320 and $340 \mathrm{~mm}$ for the $640-$ and $460-\mathrm{mm}$ subbase thicknesses, respectively. For the moist soil, the frost penetration reached a maximum of 560-mm depth. For both simulations using low moisture content soil, the frost penetration depth only reached approximately halfway into the Tilcon common granular fill material layer. 



\title{
Frost-Susceptibility Testing and Predictions for the Raymark Superfund Site
}

\author{
VINCENT C. JANOO, LYNETTE A. BARNA, AND SHERRI A. ORCHINO
}

\section{INTRODUCTION}

CRREL was approached by the Geotechnical Engineering Division of the New England Division (NED), U.S. Army Corps of Engineers, to assist in predicting the effects of freeze-thaw cycling on pavement design during the freezing season on Tilcon common granular fill. This Tilcon common granular fill is being used as the subbase material in the proposed pavement structure at the Raymark Superfund site in Stratford, Connecticut. The Tilcon fill, considered to be a clean material, comes from a source in North Branford, Connecticut.

The Raymark Superfund site is currently under remediation with the intention of using the reclaimed land for commercial development. A portion of the site is planned to be used as a parking area. The pavement structure of the proposed parking area will consist of a total of six layers of material. The uppermost layer will be composed of approximately 76 to $102 \mathrm{~mm}$ of asphalt concrete. Below this, a maximum of $203 \mathrm{~mm}$ of graded granular base will cover approximately $610 \mathrm{~mm}$ of Tilcon common granular fill. Geosynthetic liner materials, approximately $30 \mathrm{~mm}$ thick, will be placed between the Tilcon material and a sand gas collection layer (203-mm thickness). The undermost layer consists of waste material, which is a mixture of on-site soil combined with the hazardous waste that was produced on site. Asbestos, lead, PCBs, volatile organic compounds (VOCs), semi-VOCs, and solvents have been detected in the on-site soil. This mixture was treated with $3.5 \%$ cement and compacted prior to placement of the geosynthetic liner materials.

The investigation performed by CRREL is based on the projected performance of the pavement structure for both a short-term and a long-term basis. Factors associated with the pavement's performance over a long-term period include the types of soils used in the pavement structure, cracking due to loading and temperature changes, and moisture infiltration from the surface, as well as the location of the water table below the surface. The time period of interest is during the freezing season when frost heave is most damaging to a pavement structure.

CRREL conducted laboratory frost heave tests to index the frost-susceptibility of the Tilcon common granular fill. CRREL's task included predicting the amount of frost heave for the pavement structure. The computer model, FROST, was used to predict the amount of frost heave for the simulated pavement structures. All of the structures used the same material characteristics and number of layers. The first structure included a Tilcon subbase thickness of $640 \mathrm{~mm}$, and the second structure used a Tilcon subbase thickness of $460 \mathrm{~mm}$. A third set of simulations was run in which the graded base was increased from $203 \mathrm{~mm}$ to $560 \mathrm{~mm}$. The last set of simulations was tested to estimate the life of the structure based on the design loads.

This report discusses results from both the laboratory frost heave tests completed on the Tilcon common granular fill and the computer simulations. 


\section{FROST HEAVE}

Frost heave, or the raising of the surface layer because of ice in the subsurface, is detrimental to pavement structures. By increasing the amount of damage to a pavement structure, frost heaving decreases the design life of a structure, which increases the cost of either maintenance or replacement (U.S. Army and Air Force 1985). There are three necessary conditions for frost heaving: frostsusceptible soil, freezing temperatures, and the presence of water.

The frost-susceptibility of a soil depends on the amount of fines passing the no. 200 (0.074-mm) sieve. In particular, Casagrande (1931) found that he could index the frost-susceptibility of the soil as a function of the material finer than $0.02 \mathrm{~mm}$. He found soils having greater than $3 \%$ of material finer than the $0.02-\mathrm{mm}$ size appear to be highly frost-susceptible. In addition to having a frostsusceptible soil, freezing temperatures and a nearby source of water are also required for frost heave to occur. Based on the initial assessment of the Tilcon common granular fill material at CRREL, we found that the amount of fines passing the no. 200 sieve was approximately $20 \%$, of which approximately $14 \%$ was finer than $0.02 \mathrm{~mm}$ (Fig. 1). The current COE frost-susceptibility criteria limits the amount of material finer than $0.02 \mathrm{~mm}$ to $3 \%$. More explanation on the laboratory results for the Tilcon common granular fill are presented later.

\section{LABORATORY TESTING}

The Geotechnical Engineering Division at NED requested CRREL to perform laboratory testing to determine the frost-susceptibility of material identified as Tilcon common granular fill. The testing procedure used at CRREL is ASTM D591896, Standard Methods for Frost Heave and Thaw Weakening Susceptibility of Soils. This is an index test for estimating the relative degree of frostsusceptibility of a soil. This procedure cannot be used to predict the actual amount of frost heave expected nor to predict the actual strength of the soil after thaw.

Two sets of tests were conducted to assess the present and future conditions of the subbase material. In one case, the specimens were compacted at the in-situ moisture content, then saturated. These samples are referred to as saturated. This case assumes that the subbase is saturated because of the infiltration of water into the pavement system, which may occur in the later life of the pavement due to cracking. In the second case, the specimens were compacted at the in-situ moisture content and no additional water was introduced during the testing. These samples are referred to as unsaturated. This case assumes that the pavement structure is not saturated, such as in the beginning of the pavement life.

Eight samples were prepared for testing. These samples were compacted at a density of $2.2 \mathrm{~g} / \mathrm{cm}^{3}$ and a moisture content of $8 \%$. The moisturedensity data used were obtained from the NED Geotechnical Engineering Division. The samples are $146 \mathrm{~mm}$ in diameter and $150 \mathrm{~mm}$ in height. The compacted samples are confined in a split ring mold, which allows the samples to heave in an unrestricted manner.

For the saturated case, four samples were com-

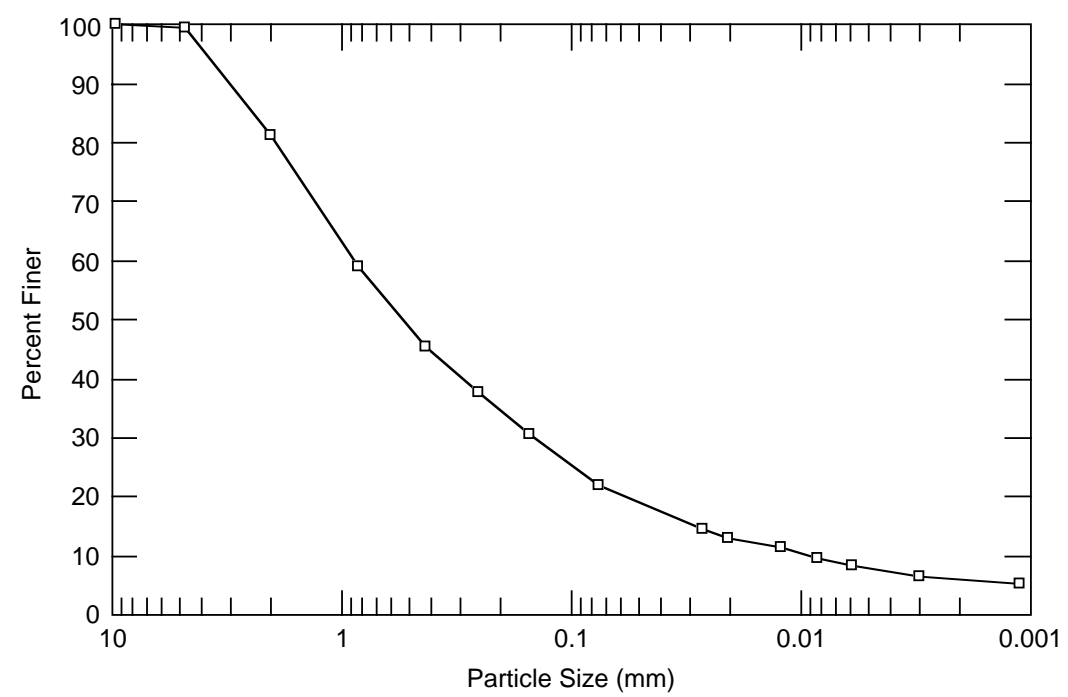

Figure 1. Grain size distribution for Tilcon common granular fill material. 
pacted, then placed in the coldroom $\left(3-4^{\circ} \mathrm{C}\right)$, and saturated by raising the water table at the rate of $25 \mathrm{~mm} /$ hour. The water table was maintained at the top of the samples overnight. The next morning, the water table was lowered to $10 \mathrm{~mm}$ above the sample bottoms and the samples were allowed to drain. All four samples had a constant water supply during testing. The specimens were then placed on the bottom warming/cooling plate. Thermocouples were installed in the samples at the top, bottom and depths of 25, 50, 75, 100 , and $125 \mathrm{~mm}$. The top cooling plates were placed on the samples along with a $5.5-\mathrm{kg}$ surcharge weight that simulates the weight of a 150mm-thick asphalt concrete pavement surface. The box was then filled with loose granular insulation.

The samples were conditioned at $3^{\circ} \mathrm{C}$ top and bottom for the first 24 hours. Following this conditioning period, the samples were subjected to four freeze-thaw cycles, rather than the ASTM standard of two cycles. Each freeze-thaw cycle consists of an initial 8-hour freeze of $-3^{\circ} \mathrm{C}$ top and $3^{\circ} \mathrm{C}$ bottom. This is followed by a 16 -hour freeze at $-12^{\circ} \mathrm{C}$ top and $0^{\circ} \mathrm{C}$ bottom to freeze the entire sample from top to bottom. A 16-hour thaw period follows at $12^{\circ} \mathrm{C}$ top and $3^{\circ} \mathrm{C}$ bottom. At completion of the thaw, the samples are again stabilized at $3^{\circ} \mathrm{C}$ top and bottom for 8 hours before the next freeze begins.

Following the final thaw period, the samples were removed from the coldroom. California Bearing Ratio (CBR) tests (ASTM test method D1883) were conducted on the samples but limited to a penetration of $7.6 \mathrm{~mm}$. The samples were then sliced horizontally into six approximately equal slices. The moisture content of these slices was determined to develop a top-to-bottom moisture profile of each specimen.

CBR tests are an index of the shearing resistance of a soil or the soil strength. The test measures the strength of a soil for specific moisture and density conditions. The shearing resistance is obtained by forcing a steel piston into a compacted soil sample at the rate of $1.27 \mathrm{~mm} /$ minute. The force required to reach $2.54 \mathrm{~mm}$ and $5.08 \mathrm{~mm}$ of penetration is measured. The measured force is converted into a ratio and compared against standard test values to obtain the CBR. The CBR is not an exact measure of the shearing modulus because of a slight influence of the confining effect of the mold. CBR generally falls between 0 and $100 \%$ with a higher value, indicating a stronger soil. CBR testing was conducted before and after frost-susceptibity tests were run to determine the loss of strength in the Tilcon material. The results are given in Table 1.

The samples in the unsaturated case were prepared and tested in the same manner as the saturated samples with three exceptions: the samples were not saturated when placed in the coldroom, a constant water supply was not connected to the samples during testing, and due to time constraints, the unsaturated samples were only subjected to two freeze-thaw cycles. An illustration of the testing apparatus is shown in Figure 2.

Testing data were collected every 5 minutes by a Northgate 486DX2 computer. LabVIEW for Windows, Version 4, was used to control two Neslab RTE-110 circulating baths. The baths controlled the temperature of the top and bottom plates on the samples, which regulated the temperature gradient and the rate of freeze in the samples. The temperature data from each ther-

Table 1. Summary of Raymark test data.

\begin{tabular}{ccccccccc} 
Sample & $\begin{array}{c}\text { Pretest } \\
\text { moisture } \\
(\%)\end{array}$ & $\begin{array}{c}\text { Post-test } \\
\text { moisture } \\
(\%)\end{array}$ & $\begin{array}{c}\text { Pretest } \\
\text { density } \\
\left(\mathrm{g} / \mathrm{cm}^{3}\right)\end{array}$ & $\begin{array}{c}\text { Pretest } \\
\text { CBR } \\
(\%)\end{array}$ & $\begin{array}{c}\text { Post-test } \\
\text { CBR } \\
(\%)\end{array}$ & $\begin{array}{c}\text { Heave } \\
\text { rate } \\
(\mathrm{mm} / \text { day })\end{array}$ & $\begin{array}{c}\text { Frost } \\
\text { design }\end{array}$ & $\begin{array}{c}\text { Classification } \\
\text { classification }^{*}\end{array}$ \\
\hline 1 & 7.66 & 10.33 & 2.26 & 45 & 4 & 20.2 & Very high & F2 \\
2 & 7.56 & 10.20 & 2.24 & 40 & 3 & 15.4 & High & F2 \\
3 & 7.11 & 10.04 & 2.45 & 43 & 3 & 15.0 & High & F2 \\
4 & 7.72 & 9.96 & 2.24 & 35 & 4 & 14.9 & High & F2 \\
5 & 8.35 & 7.91 & 2.25 & 44 & 10 & 6 & Low & F2 \\
6 & 8.25 & 8.03 & 2.26 & 45 & 9 & 4 & Medium & F2 \\
7 & 8.36 & 8.00 & 2.23 & 34 & 8 & 4 & Medium & F2 \\
8 & 8.77 & 8.12 & 2.24 & 39 & 9 & 4 & Medium & F2 \\
\hline
\end{tabular}

Note: Samples 1-4 are tested under saturated conditions; samples 5-8 are tested under in-situ conditions.

${ }^{*}$ An F2 classification indicates a frost-susceptible material with 6 to $15 \%$ of the material finer than $0.02 \mathrm{~mm}$ by weight (U.S. Army and the Air Force 1985). 


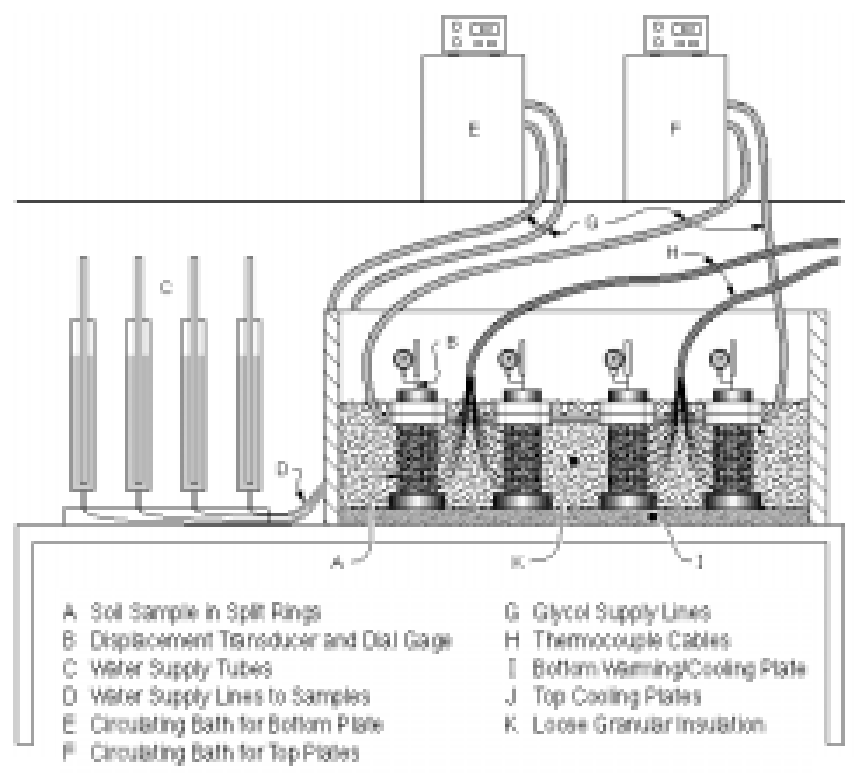

Figure 2. Laboratory testing apparatus.

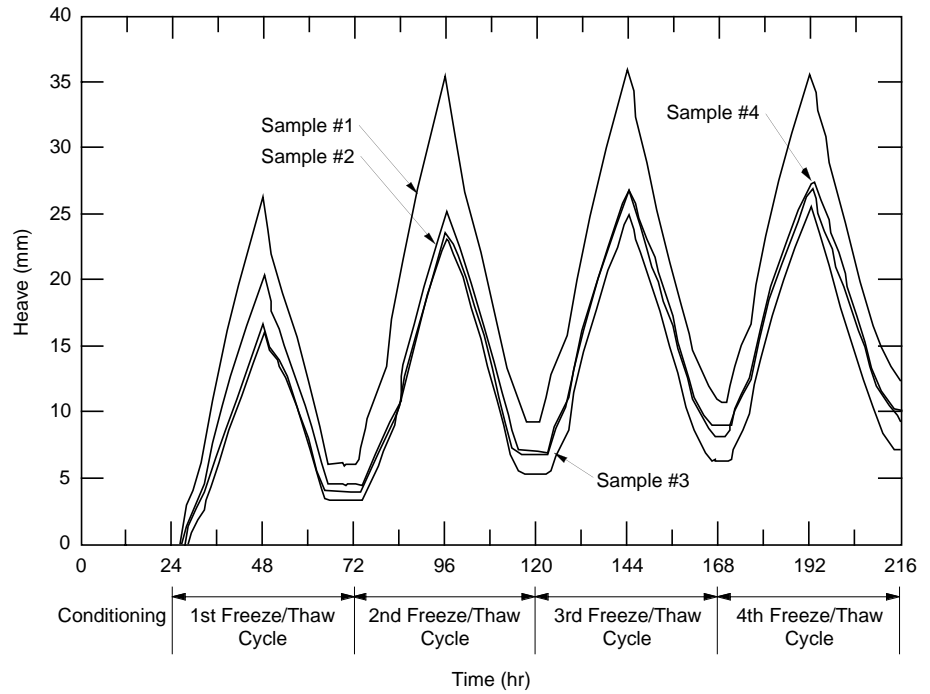

Figure 3. Frost-susceptibility testing for saturated soil samples.

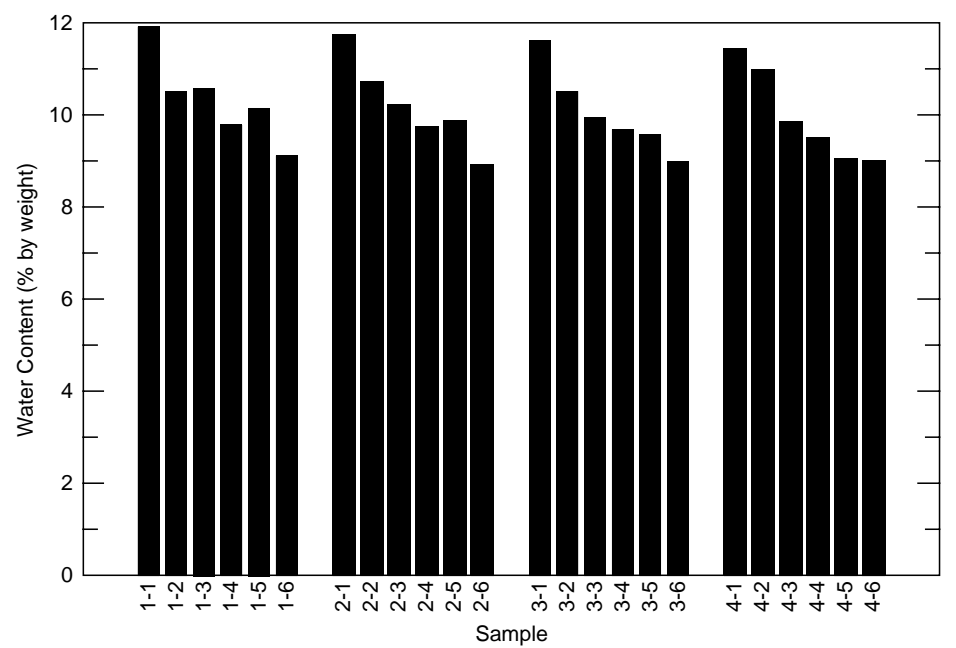

Figure 4. Sample moisture profile for saturated samples. 


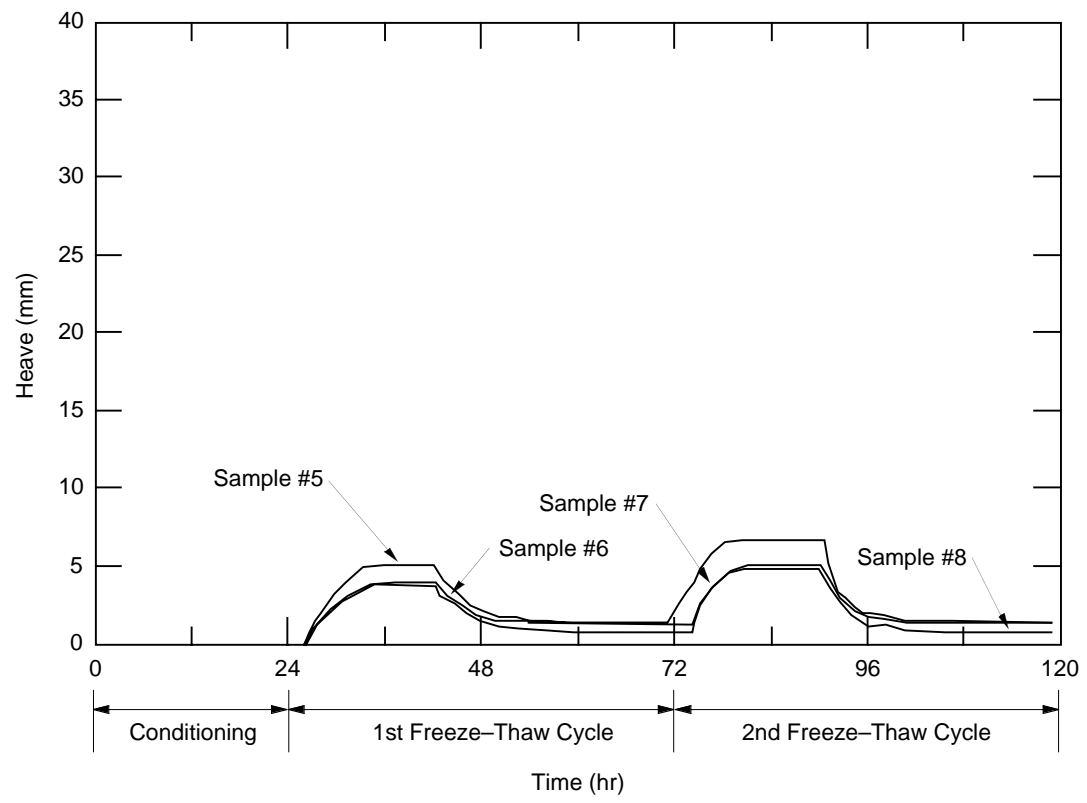

Figure 5. Frost-susceptibility testing for unsaturated soil samples.

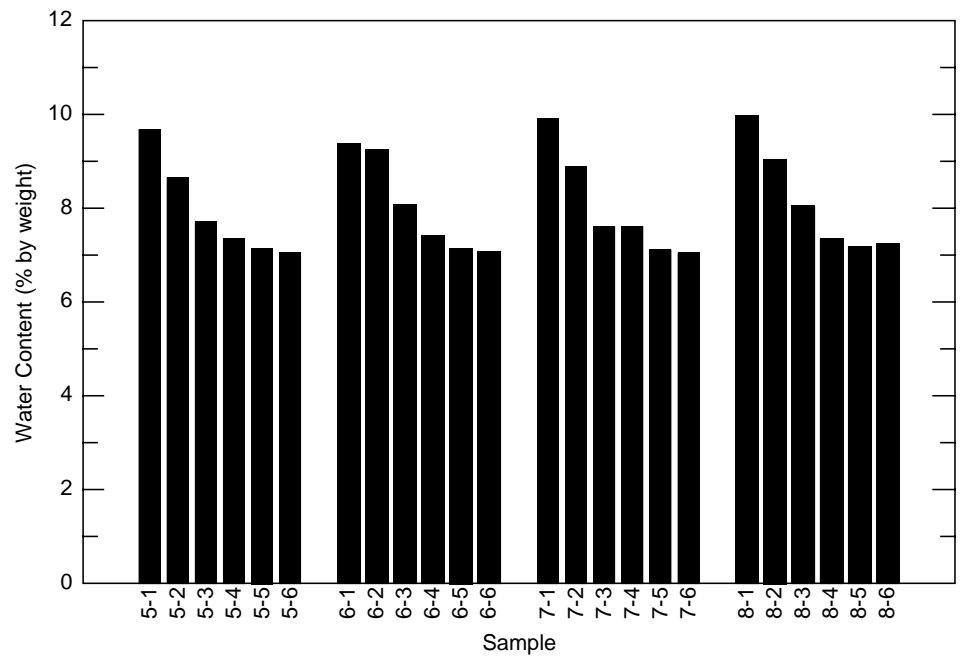

Figure 6. Sample moisture profile for unsaturated samples.

mocouple were collected hourly by a Campbell Scientific datalogger. This temperature data were used to monitor frost penetration (Fig. 3-6).

\section{LABORATORY RESULTS}

The results from the tests are shown in Table 1. The qualitative frost-susceptibility system is shown in Table 2. For the saturated Tilcon subbase soil, based on the rate of heave, the subbase material is classified as a high to very high frostsusceptible material. In the unsaturated condition, the material is classified as a low to medium frost-susceptible material.

\section{COMPUTER SIMULATION}

\section{CRREL FROST model}

The amount of frost heave expected at the Raymark site was predicted using the CRREL FROST model. This is a one-dimensional vertical heat and moisture flow model. The pavement structure, as shown in Figures 7-9, is discretized into nodes: up to 101 nodes or 100 elements. All the simulated pavement structures utilized a total of 94 nodes (or 93 elements). For ensured accuracy, node spacing in the freezing front is kept to $20 \mathrm{~mm}$ apart. The freezing front includes the pavement layers through the sand gas collection layer, below the geosynthetic liner materials. At 

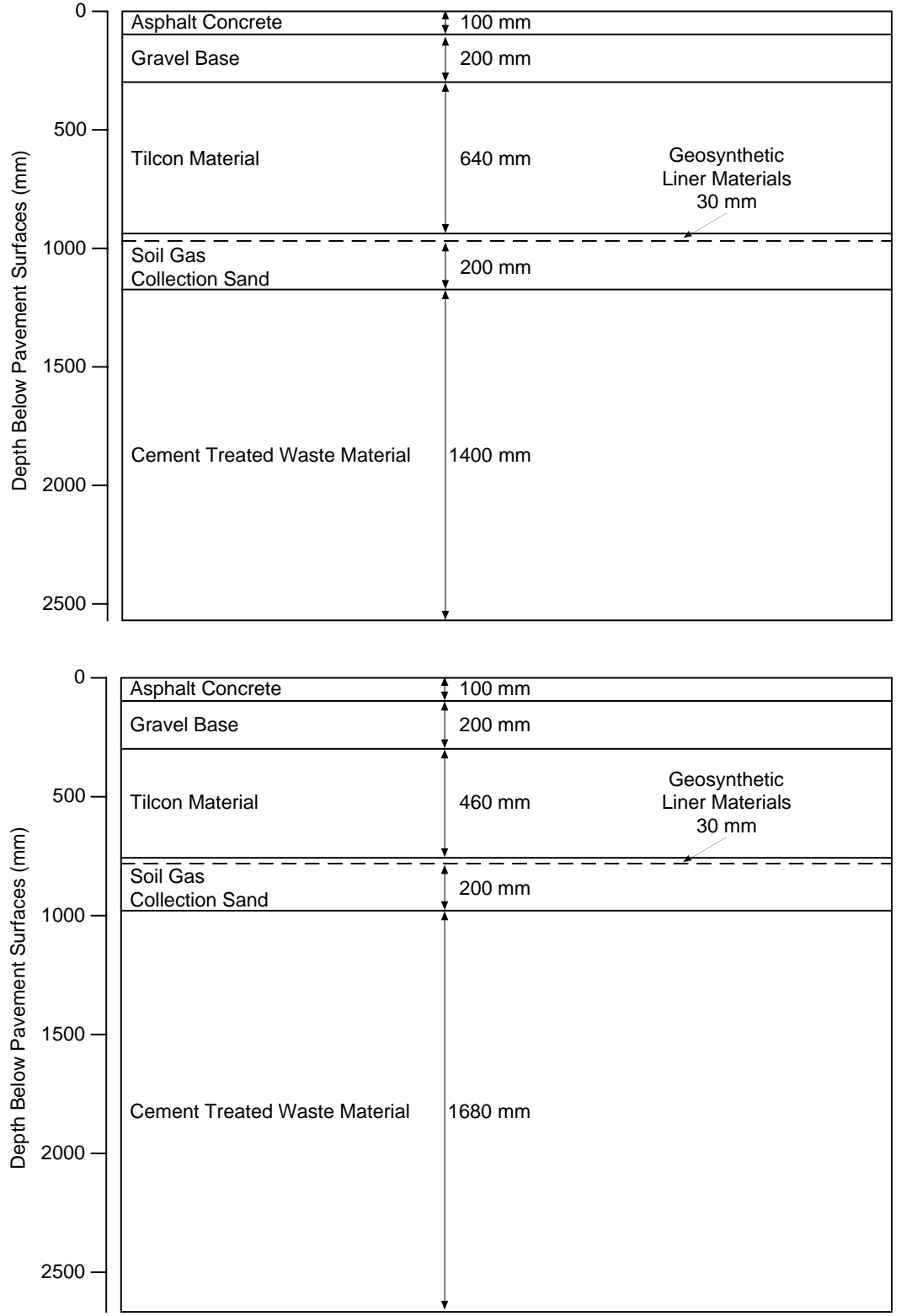

Figure 7. Pavement structure with 640-mm Tilcon layer modeled in FROST.
Figure 8. Pavement structure with 460-mm Tilcon layer modeled in FROST.
Table 2. Criteria for determining frostsusceptibility test.*

\begin{tabular}{llrr}
$\begin{array}{l}\text { Frost-susceptibility } \\
\text { classification }\end{array}$ & Symbol & $\begin{array}{c}\text { 8-hour } \\
\text { heave rate } \\
\text { (mm/day) }\end{array}$ & $\begin{array}{c}\text { Bearing ratio } \\
\text { after thaw } \\
\text { (\%) }\end{array}$ \\
\hline Negligible & NFS & $<1$ & $>20$ \\
Very Low & VL & 1 to 2 & 20 to 15 \\
Low & $\mathrm{L}$ & 2 to 4 & 15 to 10 \\
Medium & $\mathrm{M}$ & 4 to 8 & 10 to 5 \\
High & $\mathrm{H}$ & 8 to 16 & 5 to 2 \\
Very High & $\mathrm{VH}$ & $>16$ & $<2$ \\
\hline
\end{tabular}

*Typical CBR for fine-grained soils such as clays, silts, and fine sands usually range between 3\% to $15 \%$. Coarser materials (sand-silt-clay combinations and gravelly sand) range from $10 \%$ to $40 \%$. Gravelly clays, gravel-sand mixtures, and well-graded gravels can range between a CBR of $20 \%$ to $80 \%$. depths farther from the freezing front, the node spacing can be farther apart without loss of accuracy. The nodes were spaced $40 \mathrm{~mm}$ apart through the subgrade layer of the waste material. Tables 3-5 show the number of elemental lengths used in each layer in all the simulations.

The first two computer simulations were designed to predict the frost effects in the pavement structure with the Tilcon common granular fill material through the freezing season. As shown in the laboratory frost heave tests, the Tilcon material, when saturated, may be considered a highly frost-susceptible material. Since the graded aggregate base has a lower frost-susceptibility, the depth was increased from 203 to $560 \mathrm{~mm}$ to 


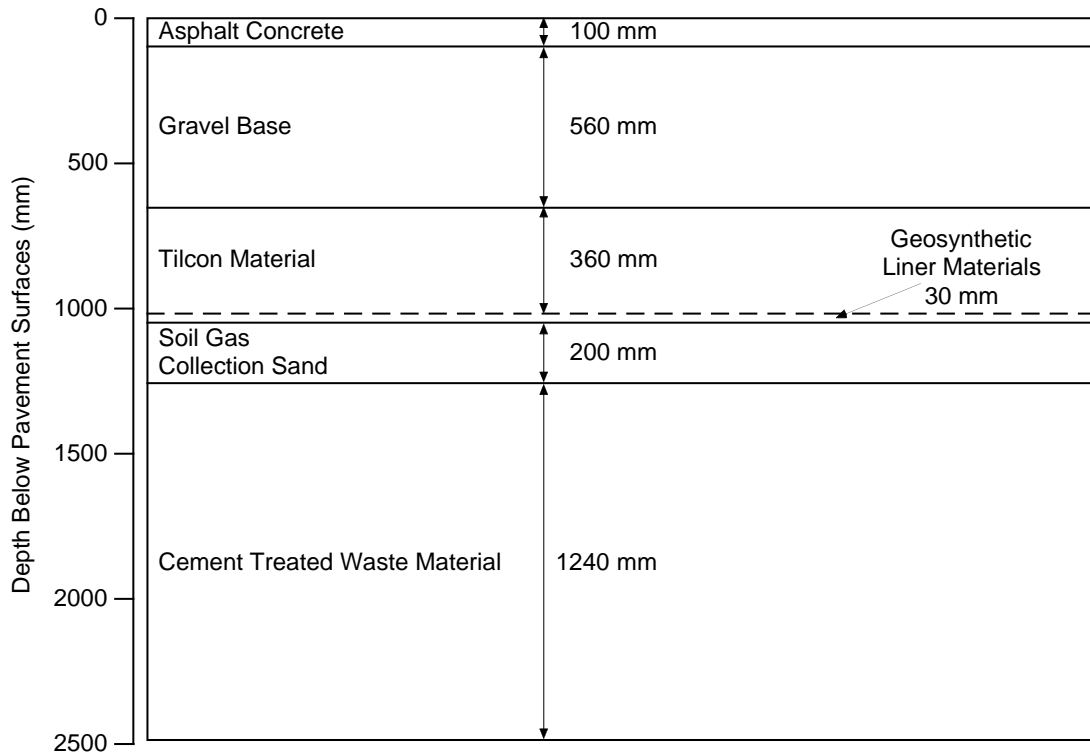

Figure 9. Pavement structure with 560-mm graded base modeled in FROST.
Table 3. Distribution of elements through pavement structure, $640-\mathrm{mm}$ Tilcon subbase layer.

\begin{tabular}{clcc}
$\begin{array}{c}\text { Layer } \\
\text { number }\end{array}$ & \multicolumn{1}{c}{ Layer type } & $\begin{array}{c}\text { Thickness } \\
\text { of layer } \\
(\mathrm{mm})\end{array}$ & $\begin{array}{c}\text { Number of } \\
\text { elements }\end{array}$ \\
\hline 1 & Asphalt concrete & 100 & 5 \\
2 & Graded aggregate base & 200 & 10 \\
3 & Tilcon common granular fill & 640 & 32 \\
4 & Geosynthetic liner materials & 30 & 1 \\
5 & Soil gas collection sand & 200 & 10 \\
6 & Cement-treated waste material & $\underline{1400}$ & $\underline{35}$ \\
& Total & 2570 & 93 \\
\hline
\end{tabular}

Table 4. Distribution of elements through pavement structure, $460-\mathrm{mm}$ Tilcon subbase layer.

\begin{tabular}{clrc}
$\begin{array}{c}\text { Layer } \\
\text { number }\end{array}$ & \multicolumn{1}{c}{ Layer type } & $\begin{array}{c}\text { Thickness } \\
\text { of layer } \\
(\mathrm{mm})\end{array}$ & $\begin{array}{c}\text { Number of } \\
\text { elements }\end{array}$ \\
\hline 1 & Asphalt concrete & 100 & 5 \\
2 & Graded aggregate base & 200 & 10 \\
3 & Tilcon common granular fill & 460 & 23 \\
4 & Geosynthetic liner materials & 30 & 1 \\
5 & Soil gas collection sand & 200 & 10 \\
6 & Cement-treated waste material & $\underline{1680}$ & $\underline{44}$ \\
& Total & 2670 & 93 \\
\hline
\end{tabular}

determine the effects in the third set of computer simulations.

Inputs into the FROST model include layer thickness, soil type, soil parameters, water table location, and air temperature data. FROST then calculates the soil temperature, moisture stress, water content, ice content, and density for each node at each designated time step throughout the simulation period. Output from FROST contains a daily prediction of the cumulative frost heave,
Table 5. Distribution of elements through pavement structure, $560-\mathrm{mm}$ base course layer.

\begin{tabular}{clcc}
$\begin{array}{c}\text { Layer } \\
\text { number }\end{array}$ & \multicolumn{1}{c}{ Layer type } & $\begin{array}{c}\text { Thickness } \\
\text { of layer } \\
(\mathrm{mm})\end{array}$ & $\begin{array}{c}\text { Number of } \\
\text { elements }\end{array}$ \\
\hline \multirow{2}{*}{$\begin{array}{l}\text { Asphalt concrete } \\
2\end{array}$} & Graded aggregate base & 100 & 5 \\
3 & Tilcon common granular fill & 560 & 28 \\
4 & Geosynthetic liner materials & 360 & 18 \\
5 & Soil gas collection sand & 200 & 1 \\
6 & Cement-treated waste material & $\underline{1240}$ & $\underline{31}$ \\
& Total & 2490 & 93 \\
\hline
\end{tabular}

the estimated rate of frost heave, and both the frost and thaw depths. Details of the model are addressed in Guymon et al. (1993). Further explanation of the input parameters as applied to the Raymark Superfund site is given below.

\section{Layer thickness}

Typically, frost penetration occurs in the base layers, but it may also occur in the subgrade layer. Increasing the thickness of the base will typically minimize the amount of frost heave. This is the intent of the last set of computer simulations where the graded aggregate base layer was increased from 200 to $560 \mathrm{~mm}$.

The pavement structures in which the thickness of the Tilcon subbase layer was varied to see the effects on frost heave and penetration. The first uses a $640-\mathrm{mm}$ subbase layer of Tilcon common granular fill below a $200-\mathrm{mm}$ graded aggregate base layer. The second pavement structure decreases the Tilcon subbase layer from 640 to $460 \mathrm{~mm}$. 


\section{Soil type and soil properties}

Since laboratory tests were not conducted on the materials currently in use for the pavement structure at the Raymark site, thermal and hydraulic properties were estimated from CRREL's soil database. Therefore, the results of all of the simulations are a best estimate from the limited amount of information on the material properties.

Table 6 provides a summary of the soil types currently in use for the Raymark Superfund site, and the soil types used in all of the computer simulations. It should be noted that the model used a low to medium frost-susceptible material as the graded aggregate base. The Tilcon common granular fill material was modeled as a well-graded sandy material and the geosynthetic liner materials were modeled using a clay material. The clay was selected because for its low permeability and is most similar to the impermeable features of the geosynthetic liner materials. at the Raymark Superfund site, groundwater is not a factor. Instead, the concern is the infiltration of moisture, from either precipitation or snowmelt, through the pavement surface into the base and subbase layers. To meet these criteria, all of the pavement structures were also modeled using a shallow (100-mm) water table and a deep (2740-mm) water table.

The deep water table represents the current insitu moisture content of the soil on site, and will be referred to as either moist soil or low moisture content throughout this report. This is also a reasonable scenario for a new pavement structure. By locating the water table at a depth far from the freezing front, the suction of moisture to the surface during freezing is minimal. This scenario also assumes the pavement structure does not permit infiltration of water through the asphalt and into the underlying layers. The shallow water table, on the other hand, represents an older pave-

Table 6. Summary of soils used in FROST model for simulation.

\begin{tabular}{|c|c|c|c|c|c|c|}
\hline \multirow[b]{2}{*}{$\begin{array}{l}\text { Soil parameters used } \\
\text { in FROST model }\end{array}$} & \multicolumn{6}{|c|}{ Material layer } \\
\hline & $\begin{array}{l}\text { Asphalt } \\
\text { concrete }\end{array}$ & $\begin{array}{c}\text { Graded } \\
\text { aggregate } \\
\text { base } \\
\mathrm{GW}^{*}\end{array}$ & $\begin{array}{c}\text { Tilcon } \\
\text { common } \\
\text { granular fill } \\
\text { SM }\end{array}$ & $\begin{array}{c}\text { Geosynthetic } \\
\text { liner } \\
\text { materials } \\
\text { CL }\end{array}$ & $\begin{array}{c}\text { Soil gas } \\
\text { collection } \\
\text { sand } \\
\text { GP }\end{array}$ & $\begin{array}{c}\text { Cement- } \\
\text { treated } \\
\text { waste } \\
\text { SP }\end{array}$ \\
\hline Soil density $\left(\mathrm{g} / \mathrm{cm}^{3}\right)$ & 2.3 & 1.84 & 1.551 & 1.69 & 2.16 & 1.61 \\
\hline Soil porosity $\left(\mathrm{cm}^{3} / \mathrm{cm}^{3}\right)$ & 0.14 & 0.3311 & 0.419 & 0.374 & 0.2 & 0.436 \\
\hline $\begin{array}{l}\text { Saturated hydraulic } \\
\text { conductivity }(\mathrm{cm} / \mathrm{hr})\end{array}$ & 2.1 & 4.7 & 1.6 & 0.14 & 0.46 & 8.1 \\
\hline $\begin{array}{l}\text { Unfrozen volumetric } \\
\text { water content }\left(\mathrm{cm}^{3} / \mathrm{cm}^{3}\right)\end{array}$ & 0.039 & 0.016189 & 0.03602 & 0.2916 & 0.0566 & 0.0198 \\
\hline
\end{tabular}

* Modeled materials (Unified Soil Symbol).

The CRREL soil database does not contain any properties on stabilized materials. To model the waste material, a poorly graded sand material was selected (denoted by the SP classification). With respect to frost heave, the pores in the stabilized material are filled with some form of stabilizing agent. In the case of the Raymark Superfund site, the stabilizing agent is cement. The addition of the stabilizing agent makes the soil impermeable and less prone to frost heave. The poorly graded sand material was chosen because it had a high porosity that reduces capillary action in the soil, thereby reducing frost heave.

\section{Water table depth}

Typically, in a FROST simulation, the location of the water table below the pavement surface will have an impact on the computer results. However, ment where moisture infiltration occurs through cracks in the surface layer. This scenario assumes that the subsurface layers $100 \mathrm{~mm}$ below the surface are completely saturated, even during freezing. This scenario will be referred to as either the fully saturated or saturated case throughout this report.

\section{Temperature data}

In addition to the material properties, the air temperature during the freezing season is required as input for the model. The air temperatures were selected based on the design freezing index (DFI) (Johnson et al. 1975). Daily minimum and maximum temperatures from 1965-1996 recorded from the Bridgeport Airport were used to determine the DFI. This weather station is the closest to the Raymark Superfund site in Strat- 
Table 7. Example of determining cumulative degree-days.

\begin{tabular}{cccc} 
Average daily & & \\
temperature & & $\begin{array}{c}\text { Degree-days } \\
\left({ }^{\circ} \mathrm{C}\right)\end{array}$ & $\begin{array}{c}\text { Cumulative } \\
\text { Day }\end{array}$ \\
\hline & & & 8 \\
1 & 8 & +8 & 18 \\
2 & 10 & +10 & 27 \\
3 & 9 & +9 & 32 \\
4 & 5 & +5 & 35 \\
5 & 3 & +3 & 37 \\
6 & 2 & +2 & \\
\hline
\end{tabular}

ford, Connecticut. For each freezing season, which typically ranged from 1 November through 31 March, an average daily temperature $\left({ }^{\circ} \mathrm{C}\right)$ was determined and used to calculate cumu- lative degree-days. A degree-day is negative when the average daily temperature is below $0^{\circ} \mathrm{C}$ and positive when the average daily temperature is above $0^{\circ} \mathrm{C}$ (Johnson et al. 1975). An example of the cumulative degree-day calculation is shown in Table 7. A typical curve of cumulative degree days as a function of the freezing season for Bridgeport, Connecticut, is shown in Figure 10. This freezing curve illustrates the period of time prior to and throughout the freezing season until thaw occurs. The annual freezing index (AFI) is the numeric difference between the maximum and minimum locations of the curve. A larger AFI value indicates a season with lower temperatures. For Bridgeport, the three highest AFI values occurred in 1993-94 (291), 1977-78 (272), and

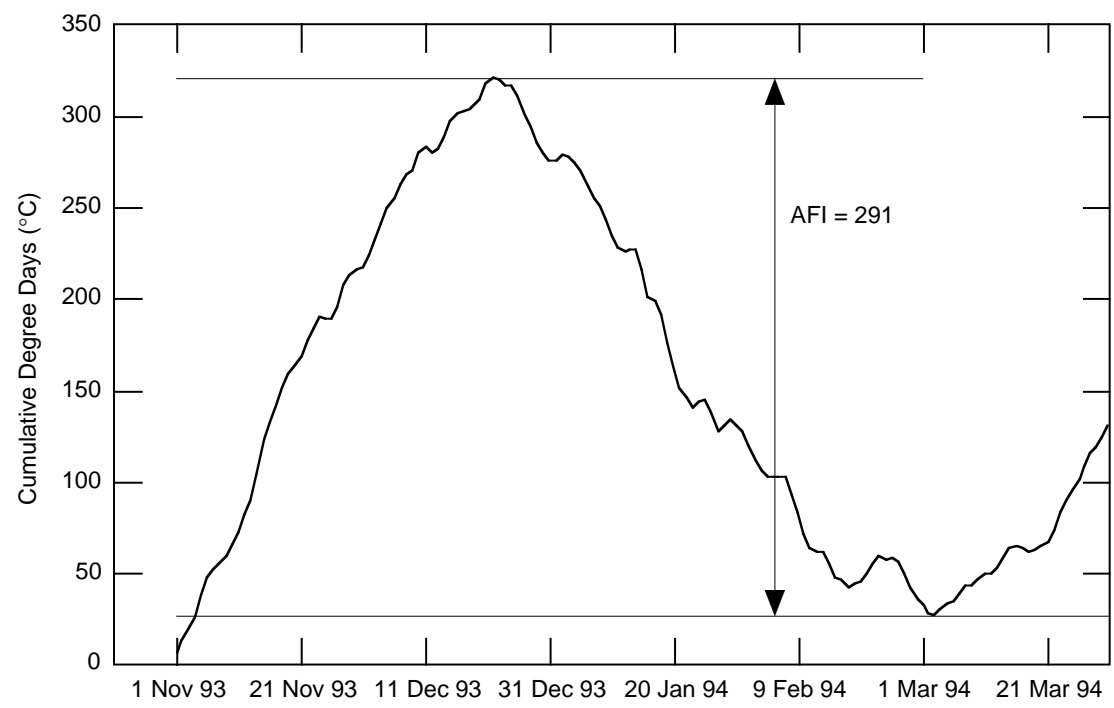

Figure 10. Annual freezing index curve for 1993-94 freezing season.

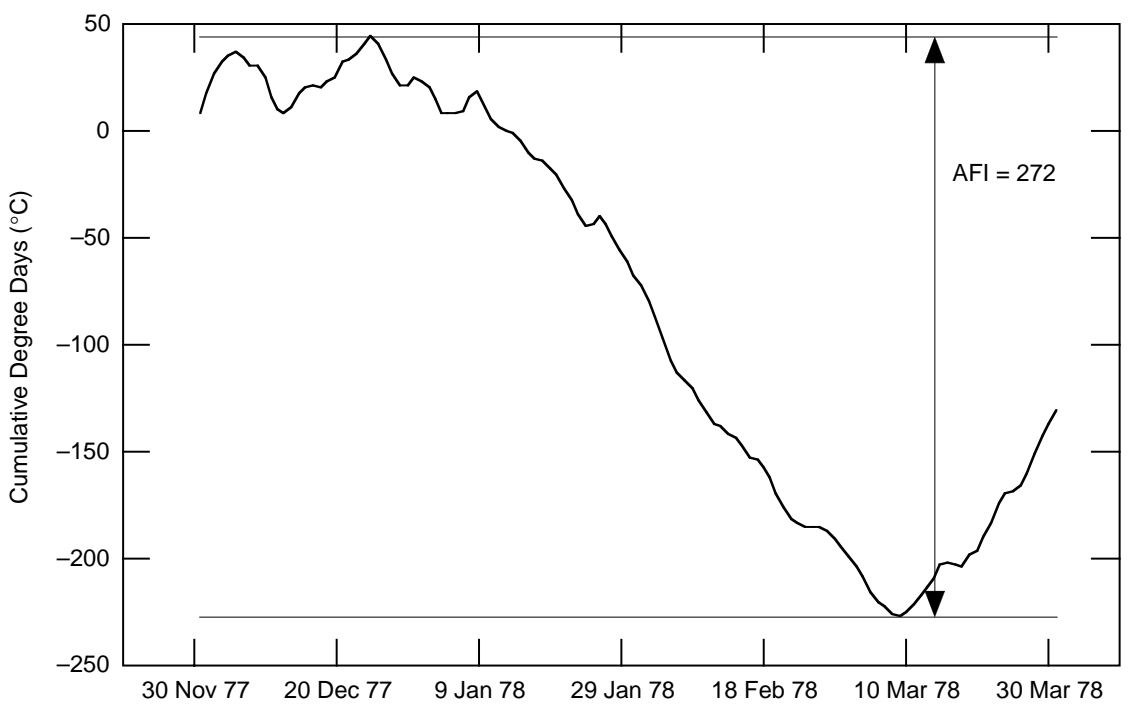

Figure 11. Annual freezing index curve for 1977-78 freezing season. 


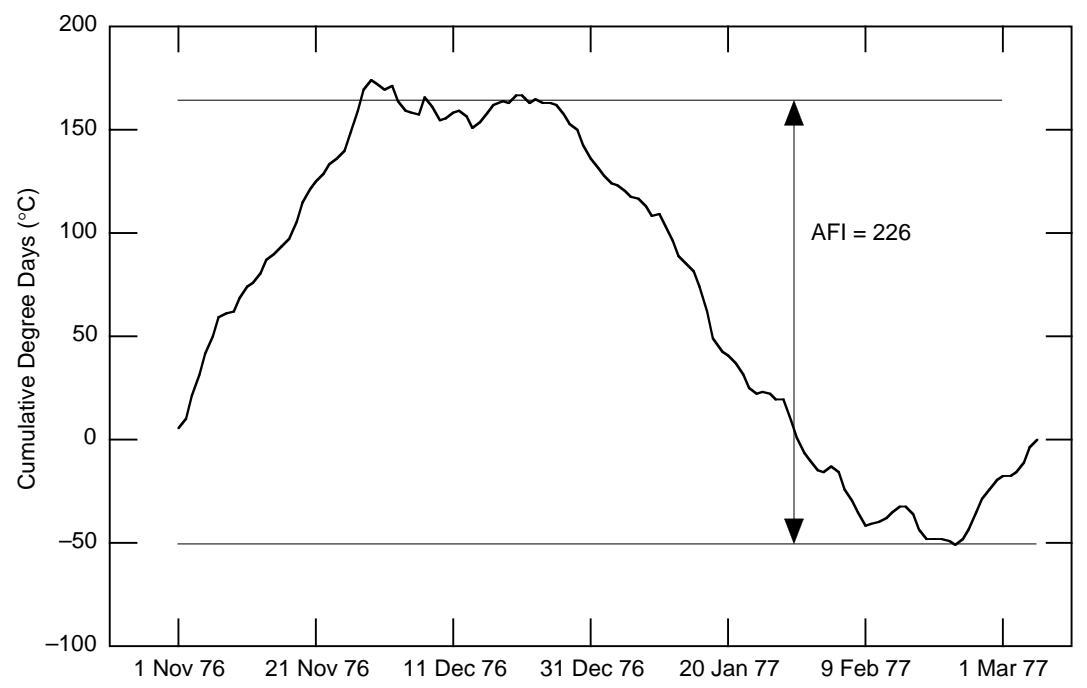

Figure 12. Annual freezing index curve for 1976-77 freezing season.

Table 8. Determination of DFI.

\begin{tabular}{cc} 
Coldest freezing seasons & AFI value \\
\hline 1993-94 & 291 \\
$1977-78$ & 272 \\
$1976-77$ & 226 \\
\hline Average of three AFI values: & 263 \\
Freezing season closest to average: & $1977-78$ \\
\hline
\end{tabular}

1976-77 (226) (Fig. 10-12). The average of these three coldest freezing seasons was calculated and the single season with an AFI value closest to the average AFI is used in the simulations (see Table 8). The DFI is calculated by averaging the values of the three coldest freezing seasons.

The DFI value was calculated at $263^{\circ} \mathrm{C}$-days. The 1977-78 freezing season, with an AFI value of $272^{\circ} \mathrm{C}$-days, corresponded the closest to the DFI. The temperature data from the 1977-78 season were used in the computer simulation (Fig. 13). It should be noted that the temperature data used in the computer simulation is slightly colder than the calculated DFI value. This provides a more conservative estimate for the prediction of frost penetration on the pavement structure. The simulation was run over a 151-day period, simulating the freezing season from 1 November through 31 March.

\section{COMPUTER SIMULATION RESULTS}

640-mm Tilcon subbase material thickness

Both the input and the output files for the

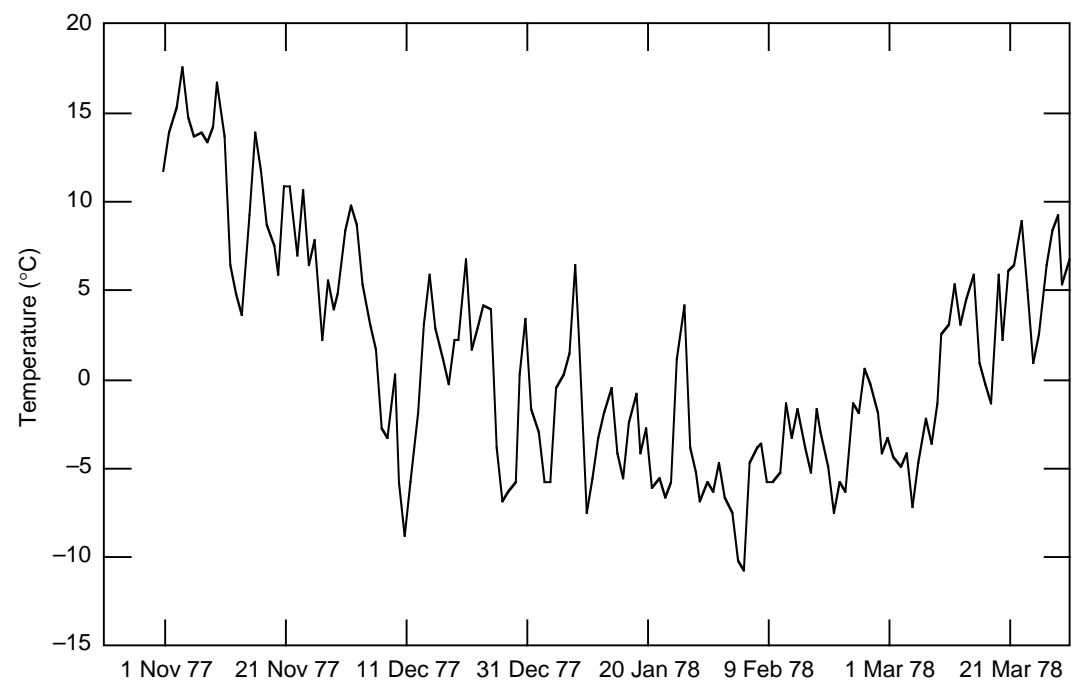

Figure 13. Average daily temperature curve for 1977-78 freezing season. 
640-mm Tilcon common granular fill subbase layer for both the in-situ and saturated moisture conditions are presented in Appendices B and C in Internal Report 1179.* The upper layers of this pavement structure included $100 \mathrm{~mm}$ of asphalt, $200 \mathrm{~mm}$ of graded aggregate base, and $640 \mathrm{~mm}$ of Tilcon common granular fill. The output from FROST provides daily cumulative minimum, maximum, and mean estimates for frost heave, as well as estimates for both the frost and thaw depth. Results for frost heave are shown in Figure 14. When the water table was placed $2740 \mathrm{~mm}$ below the surface, simulating a pavement with a low moisture content, the cumulative heave was $3.8 \mathrm{~mm}$. This may be considered a low amount of frost heave. When the water table was located $100 \mathrm{~mm}$ below the pavement surface, simulating a fully saturated soil, the maximum cumulative mean heave for the Raymark site during a single freeze-thaw cycle was approximately $68 \mathrm{~mm}$. The predicted amount of heave could be classified as high when the soil was modeled under fully saturated conditions.

Predictions of frost penetration into the soil during the freezing season reached $500 \mathrm{~mm}$ with a moist soil, and $320 \mathrm{~mm}$ with a saturated soil (Fig. 15). The frost depth penetrates to a maximum depth of $200 \mathrm{~mm}$ into the Tilcon material layer, less than halfway through the layer, and does not extend down to the geosynthetic liner.

\section{0-mm Tilcon material thickness}

At the request of NED, a computer simulation using $100 \mathrm{~mm}$ of asphalt concrete, $200 \mathrm{~mm}$ of graded aggregate base and $460 \mathrm{~mm}$ of the Tilcon common granular fill was run. This scenario was

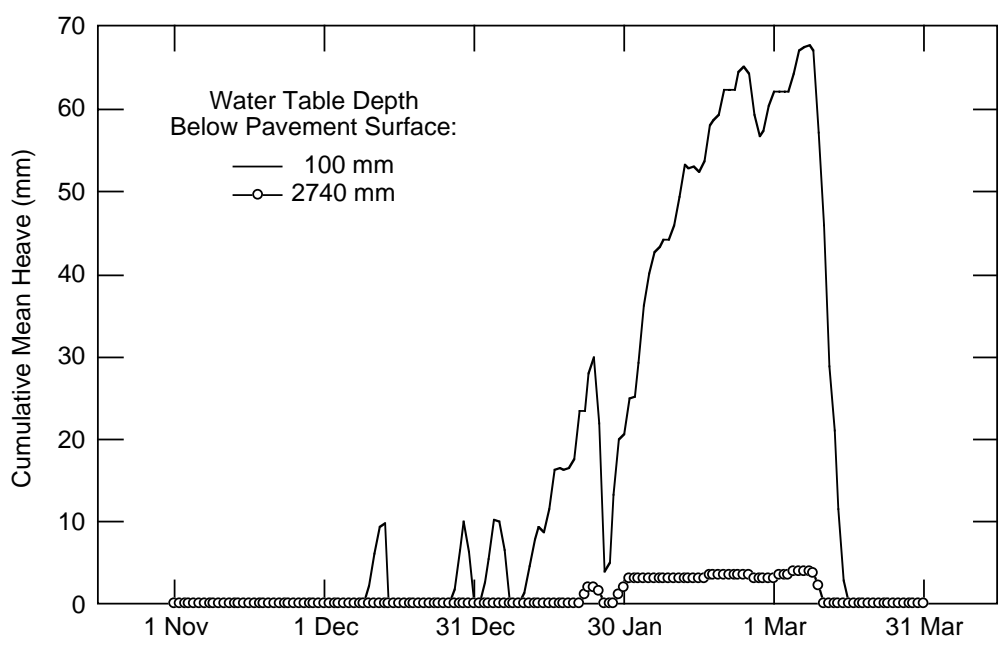

Figure 14. FROST prediction of cumulative mean heave-640-mm subbase layer.

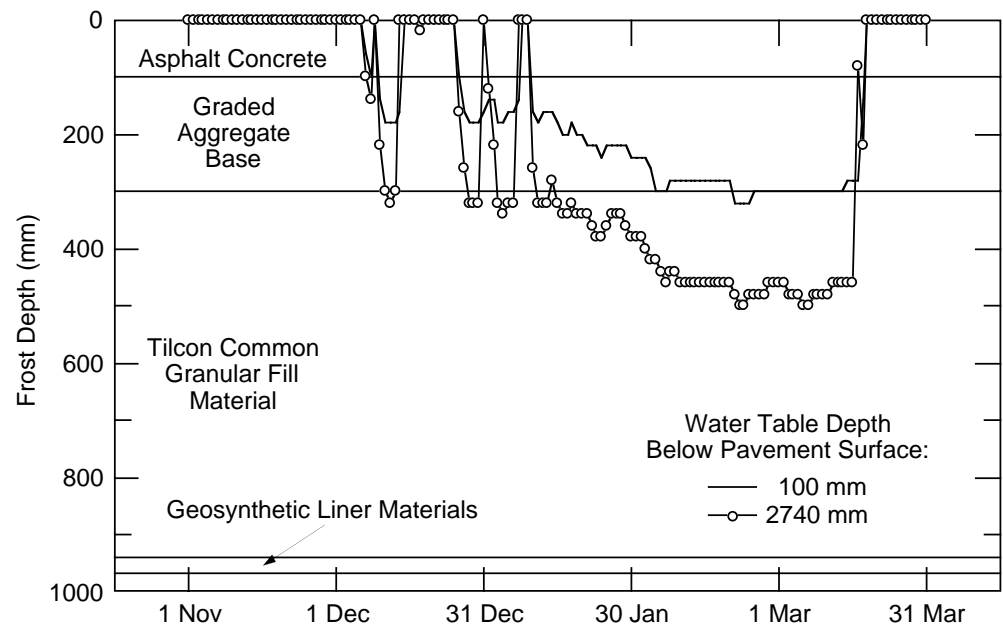

Figure 15. FROST prediction of frost penetration-640-mm subbase layer.

\footnotetext{
* Internal Report 1179 is available from the authors.
} 


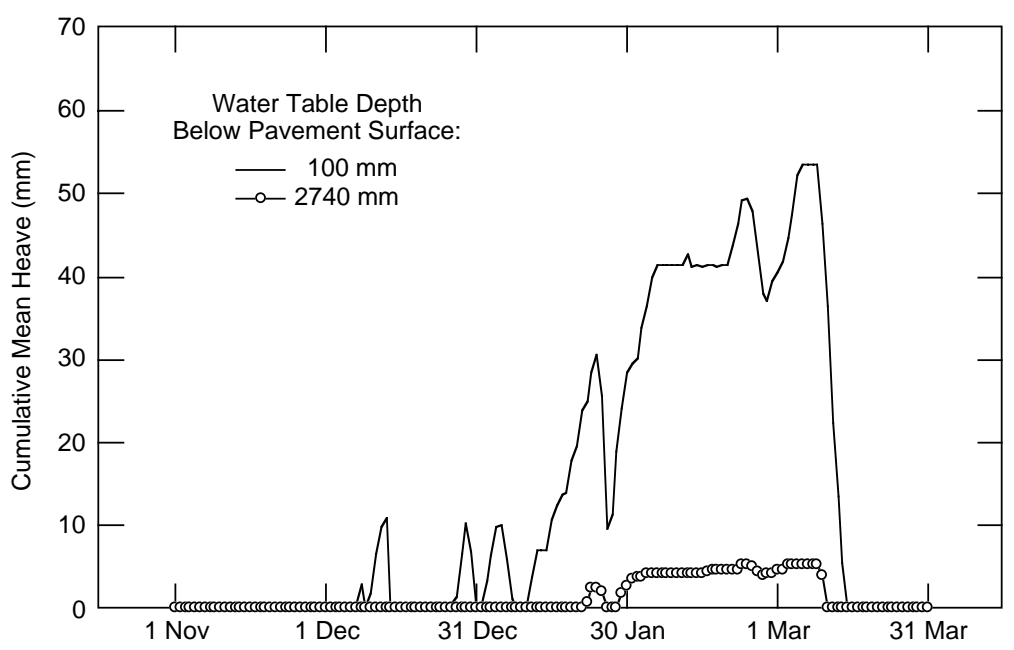

Figure 16. FROST prediction of cumulative mean heave-460-mm subbase layer.

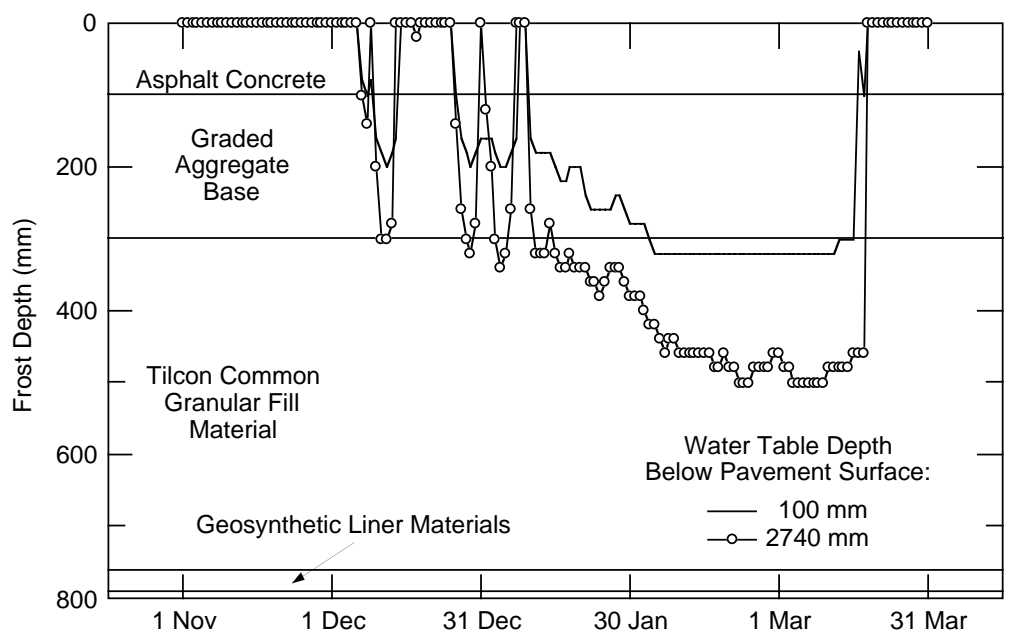

Figure 17. FROST prediction of frost penetration-460-mm subbase layer.

created to see how great an effect a reduced subbase thickness would have on frost heave and penetration. The input and output files for both moisture contents are included in Appendices D and $\mathrm{E}$ in Internal Report 1179. Results for the predicted frost heave are given in Figure 16. For frost heave, decreasing the thickness of the Tilcon material layer containing a moist soil increased the amount of expected frost heave to $5.1 \mathrm{~mm}$. Even with this increase, the frost heave is still classified as low. For the saturated soil, the predicted amount of frost heave was $53 \mathrm{~mm}$.

Even with a decrease in the Tilcon layer of $180 \mathrm{~mm}$, frost penetration remained the same. Estimated frost depths were $500 \mathrm{~mm}$ for a moist soil and $320 \mathrm{~mm}$ under saturated soil conditions (Fig. 17).

\section{0-mm graded aggregate base thickness}

The results of the simulation using $560 \mathrm{~mm}$ of graded aggregate base estimated that no frost heave would occur under in-situ conditions. The results using a saturated structure show that the estimated frost heave is $61 \mathrm{~mm}$ (Fig. 18). Frost penetration, under in-situ conditions, is estimated to reach $680 \mathrm{~mm}$. This depth reaches into the very top of the subgrade. For the saturated conditions, the frost depth only reaches $280 \mathrm{~mm}$ (Fig. 19). This frost depth is $40 \mathrm{~mm}$ less than either of the first simulations. Appendices $F$ and $G$ in Internal Report 1179 contain the input and output files for this simulation. Table 9 provides a summary of the computer simulations.

Table 9 illustrates that a reduction in frost heave occurs when a thicker aggregate base layer composed of relatively non-frost-susceptible 


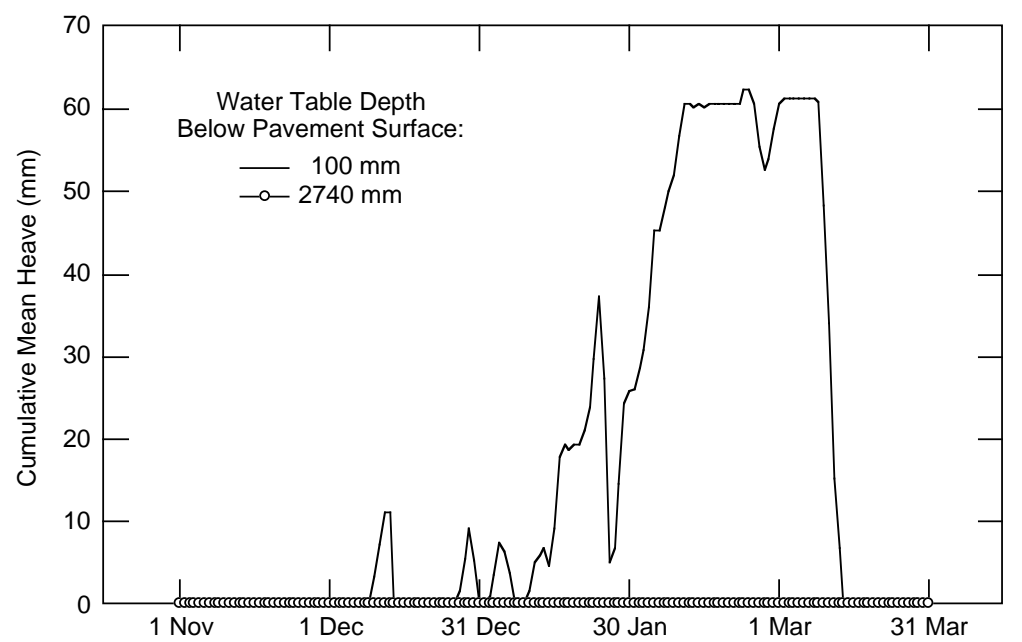

Figure 18. FROST prediction of cumulative mean heave-560-mm base layer.

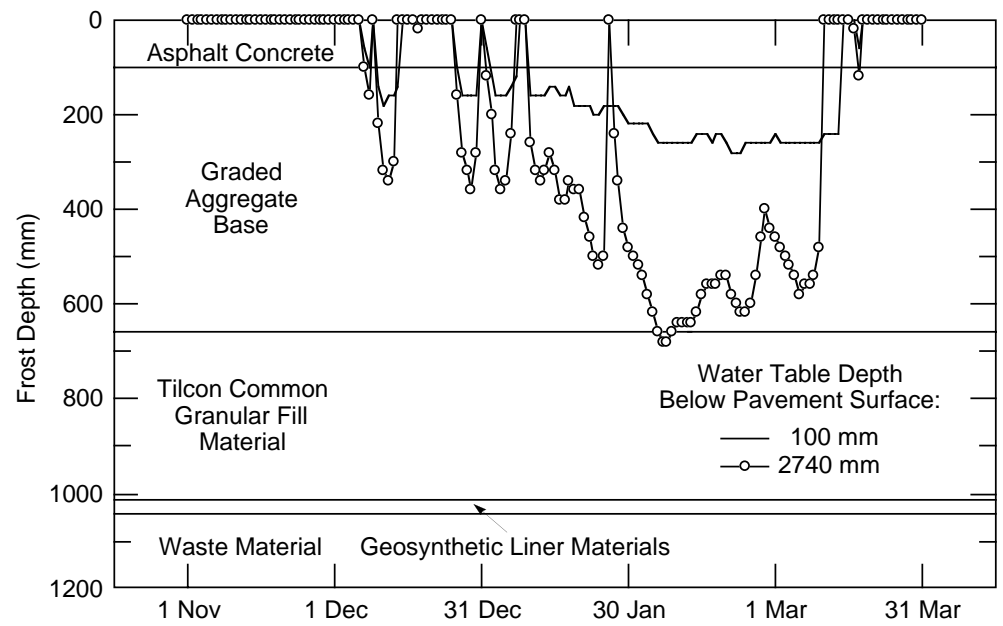

Figure 19. FROST prediction of frost penetration-560-mm base layer.

Table 9. Summary of frost heave and frost depth predictions from computer simulation.

Pavement structure with 100-mm asphalt concrete over $200 \mathrm{~mm}$ of graded aggregate base

$$
\text { 2740- } 100-\mathrm{mm}
$$

$\frac{\text { Thickness }(\mathrm{mm})}{\text { Tilcon common }} \frac{\text { water table depth }}{\text { Frost heave Frost depth }} \frac{\text { water table depth }}{\text { Frost heave Frost depth }}$

\begin{tabular}{ccccc}
$\begin{array}{c}\text { granular fill } \\
\text { gron common }\end{array}$ & $\begin{array}{c}\text { Frost heave } \\
(\mathrm{mm})\end{array}$ & $\begin{array}{c}\text { Frost depth } \\
(\mathrm{mm})\end{array}$ & $\begin{array}{c}\text { Frost heave } \\
(\mathrm{mm})\end{array}$ & $\begin{array}{c}\text { Frost depth } \\
(\mathrm{mm})\end{array}$ \\
\hline 640 & 3.8 & 500 & 68 & 320 \\
460 & 5.1 & 500 & 53 & 320
\end{tabular}

Pavement structure with 100-mm asphalt concrete over $560 \mathrm{~mm}$ of graded aggregate base

$$
\text { Graded }
$$

aggregate

base

560

0.0

680

61 
material is used under in-situ conditions. Under saturated moisture conditions, the amount of frost heave and frost depth is approximately the same for all of the computer simulations. This may be the case if the pavement layer is cracked and water and fine material are allowed to flow into the base/subbase layer and the pavement structure should become fully saturated.

One of the problems with the FROST model is that it is unable to account for drainage during the frost heave process. Materials that have a low amount of fines passing the $0.074-\mathrm{mm}$ sieve will drain and have less suction to draw water toward the freezing front.

To further study the effect of increasing the base course layer to $560 \mathrm{~mm}$, the simulations were run again, and the water table was placed at a depth of $940 \mathrm{~mm}$ below the surface of the pavement for both the structure using $640 \mathrm{~mm}$ of Tilcon fill and the structure using $560 \mathrm{~mm}$ of graded aggregate base (Fig. 7 and 9). The results from these simulations showed no frost heave occurring in the 560-mm graded aggregate base course structure.

\section{CUMULATIVE DAMAGE}

Pavement structures will degrade over time due to frost heave and thaw weakening, and the anticipated loading from traffic. A damage model can be used to predict the rate of this degradation. The pavement design specifications proposed for the Raymark Superfund site for heavy-duty traffic was based on a design life of 20 years, and estimating an equivalent axle load (EAL) between 7.0 and 46.0 per day. The CRREL SLED model (Seasonal Layered Elastic Design) was used to create a multilayered pavement structure, which estimated strain values at the bottom of the pavement layer and the top of the subgrade layer. SLED is composed of four computer programs. The first program is FROST, which estimates frost heave and frost depths. TRANSFRM uses the daily output from FROST to produce output files of layered pavement systems with estimated modulus values. The output files from TRANSFRM are used as input into NELAPAV (Nonlinear Elastic Layer Analysis for PAVements), which calculates the strains within a layered pavement system (Irwin and Speck 1986). Finally, damage estimations were calculated using the Shell damage model (Huang 1993). The Shell damage model uses the following equations:

$$
\text { Damage }=\frac{\text { Number of Applications }}{N_{\text {design }}}
$$

where Number of Applications is the design applications, where $N_{\text {design }}$ for the bottom of the pavement is calculated using

$$
N_{\text {design }}=0.0685\left(\text { Strain }_{\text {horizontal }}\right)^{-5.671}\left(M_{\mathrm{r}}\right)^{-2.363}(2)
$$

where $N_{\text {design }}=$ the number of calculated applications

Strain $_{\text {horizontal }}=$ the calculated tensile strain

$M_{\mathrm{r}}=$ modulus value of the material (psi).

$N_{\text {design }}$ for the top of the subgrade is calculated using

$$
N_{\text {design }}=1.94 \times 10^{-7}\left(\text { Strain }_{\text {vertical }}\right)^{-4.0}
$$

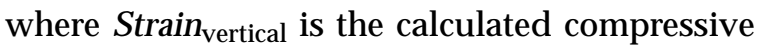
strain.

Damage calculations were only performed on the $560-\mathrm{mm}$ base course pavement structure, since this structure is representative of the specified design. It should be noted that only the structure simulating moist (not saturated conditions) was investigated.

Estimated damage is calculated on a daily basis and summed for a 1-year period to obtain a total estimate of damage to the pavement structure (otherwise known as Miner's rule). Using this, failure occurs when Damage equals or exceeds 1.0. Therefore, for a section to last its design life, the value of the calculated damage value should not accumulate to 1.0 until the design period expires. Damage was calculated based on both 7 and 46 EALs per day. The estimated amount of cumulative damage calculated in the first year using 46 EALs per day was 0.0076 at the bottom of the pavement and 0.001 at the top of the subgrade (Fig. 20 and 21). Based on a linear summation of daily damage, the results suggest that the pavement structure will not fail from either fatigue nor subgrade rutting during its design life. Results of the damage calculations are given in Appendix H in Internal Report 1179.

\section{CONCLUSIONS}

Laboratory frost heave tests indicate that the Tilcon common granular fill may be classified as of low to medium frost-susceptibility. However, if the material becomes saturated, the tests indicate that the material is highly frost-susceptible. 


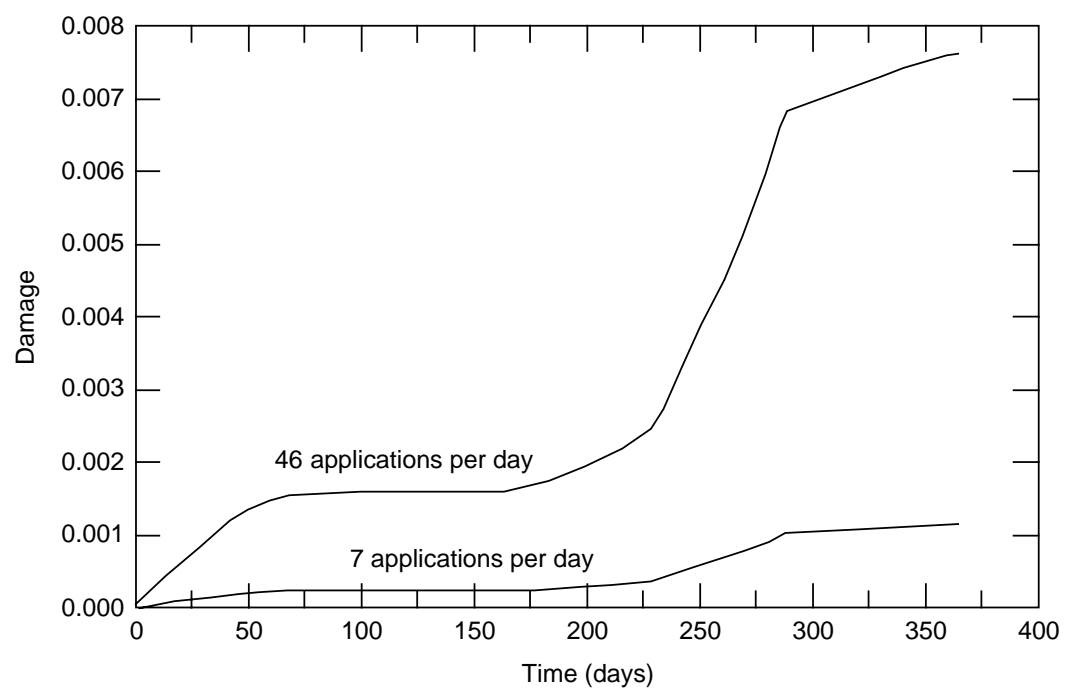

Figure 20. Cumulative damage for first year-at bottom of pavement.

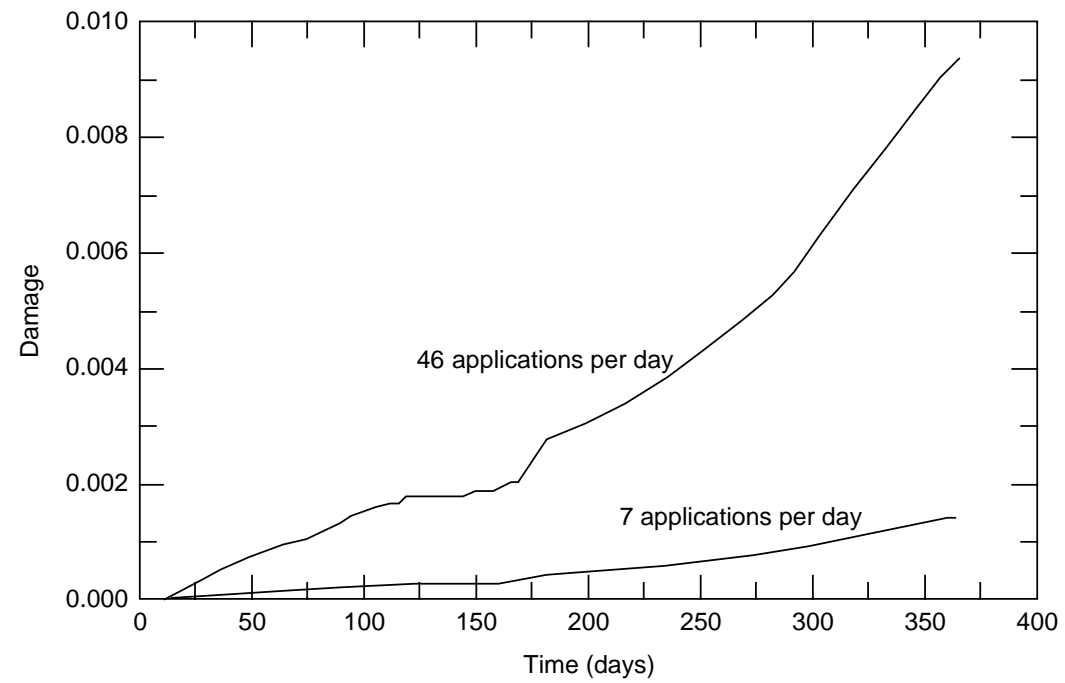

Figure 21. Cumulative damage for first year - at top of subgrade.

The results from the computer simulations agree with the laboratory findings. Estimates of frost heave based on the CRREL FROST model and assumed material properties indicate very minimal frost heave $(<10 \mathrm{~mm})$ under in-situ moisture conditions. If for some unforeseen reasons, the pavement structure soil becomes saturated, as demonstrated by modeling a worst case scenario, the amount of frost heave estimated was in the vicinity of $50-70 \mathrm{~mm}$.

Finally, the results from the damage calculations suggest that the pavement structure will not fail from either fatigue or subgrade rutting during its design life.

\section{LITERATURE CITED}

American Society for Testing and Materials (1996) Standard test methods for frost heave and thaw weakening susceptibility of soils. American Society for Testing and Materials, West Conshohocken, Pennsylvania, D-5918-96.

American Society for Testing and Materials (1996) CBR (California Bearing Ratio) of laboratorycompacted soils. American Society for Testing and Materials, West Conshohocken, Pennsylvania, D-1883-94.

Casagrande, A. (1931) Discussion of frost heaving. Highway Research Board, Proceedings, p.168-172.

Guymon, G.L., R.L. Berg, and T.V. Hromadka (1993) Mathematical model of frost heave and 
thaw settlement in pavements. USA Cold Regions Research and Engineering Laboratory, CRREL Report 93-2.

Huang, Y. H. (1993) Pavement Analysis and Design. New York: Simon \& Schuster Company.

Irwin, L. H., and D. P. T. Speck (1986) NELAPAV user's guide. Cornell Local Roads Program, Report no. 86-1, Cornell University.
Johnson, T.C., R.L. Berg, K.L. Carey, and C.W. Kaplar (1975) Roadway design in seasonal frost areas. USA Cold Regions Research and Engineering Laboratory, Technical Report 259.

U.S. Army and Air Force (1985) Pavement design for seasonal frost conditions. Departments of the Army and the Air Force, Technical Manual no. 5818-2, Washington, DC. 
Public reporting burden for this collection of information is estimated to average 1 hour per response, including the time for reviewing instructions, searching existing data sources, gathering and maintaining the data needed, and completing and reviewing the collection of information. Send comments regarding this burden estimate or any other aspect of this collection of information, including suggestion for reducing this burden, to Washington Headquarters Services, Directorate for Information Operations and Reports, 1215 Jefferson Davis Highway, Suite 1204 , Arlington, VA 22202-4302, and to the Office of Management and Budget, Paperwork Reduction Project (0704-0188), Washington, DC 20503.

\begin{tabular}{|l|l|l|}
\hline 1. AGENCY USE ONLY (Leave blank) & $\begin{array}{l}\text { 2. REPORT DATE } \\
\text { December } 1997\end{array}$ & 3. REPORT TYPE AND DATES COVERED \\
\hline
\end{tabular}

4. TITLE AND SUBTITLE

Frost-Susceptibility Testing and Predictions for the Raymark Superfund Site

6. AUTHORS

Vincent Janoo, Lynette Barna, and Sherri Orchino

7. PERFORMING ORGANIZATION NAME(S) AND ADDRESS(ES)

U.S. Army Cold Regions Research and Engineering Laboratory

72 Lyme Road

Hanover, New Hampshire 03755-1290

8. PERFORMING ORGANIZATION

REPORT NUMBER

Special Report 97-31

9. SPONSORING/MONITORING AGENCY NAME(S) AND ADDRESS(ES)

New England District

U.S. Environmental Protection Agency

10. SPONSORING/MONITORING AGENCY REPORT NUMBER

U.S. Army Corps of Engineers Washington, D.C. 20460

424 Trapelo Road

Waltham, Massachusetts 02254-9149

11. SUPPLEMENTARY NOTES For conversion of SI units to non-SI units of measurement consult Standard Practice for Use of the International System of Units (SI), ASTM Standard E380-93, published by the American Society for Testing and Materials, 1916 Race St., Philadelphia, Pa. 19103.

12a. DISTRIBUTION/AVAILABILITY STATEMENT 12b. DISTRIBUTION CODE

Approved for public release; distribution is unlimited.

Available from NTIS, Springfield, Virginia 22161.

13. ABSTRACT (Maximum 200 words)

This project was conducted to assist in predicting the effects of freeze-thaw cycling on Tilcon common granular fill during the freezing season. This material is being used as the subbase material in the proposed pavement structure at the Raymark Superfund site in Stratford, Connecticut. Based on the initial laboratory results of the Tilcon material performed at CRREL, the amount of fines passing the no. 200 sieve was found to be in the vicinity of $20 \%$, of which approximately $14 \%$ was finer than $0.02 \mathrm{~m}$. Results from the frost heave tests indicate that when the Tilcon material is saturated, based on the rate of heave, the material is classified a high to very high frostsusceptible material. In the unsaturated condition, the material is classified as a low to medium frost-susceptible material. Computer simulations were run to predict the amount of frost heave and frost penetration that may be expected on this site during the freezing season. Results from the laboratory frost-susceptibility tests and computer simulations were then used to estimate the amount of cumulative damage to the pavement structure during its design life.

\begin{tabular}{|c|c|c|}
\hline \multicolumn{3}{|l|}{ 14. SUBJECT TERMS } \\
\hline Base course & Frost heave & Subbase \\
\hline Flexible pavement design & Frost susceptibility & Thaw weakening \\
\hline Freeze-thaw cycling & Pavement & \\
\hline $\begin{array}{l}\text { 17. SECURITY CLASSIFICATION } \\
\text { OF REPORT }\end{array}$ & $\begin{array}{l}\text { 18. SECURITY CLASSIFICATION } \\
\text { OF THIS PAGE }\end{array}$ & $\begin{array}{l}\text { 19. SECURITY CLASSIFICATION } \\
\text { OF ABSTRACT }\end{array}$ \\
\hline UNCLASSIFIED & UNCLASSIFIED & UNCLASSIFIED \\
\hline
\end{tabular}

15. NUMBER OF PAGES 21

16. PRICE CODE

20. LIMITATION OF ABSTRACT

$\mathrm{UL}$

Standard Form 298 (Rev. 2-89) Prescribed by ANSI Std. Z39-18 298-102 